\title{
KESEJAHTERAAN PSIKOLOGIS LANSIA JANDA/DUDA DITINJAU DARI PERSEPSI TERHADAP DUKUNGAN SOSIAL DAN GENDER
}

\author{
Dinie Ratri Desiningrum \\ Fakultas Psikologi Universitas Diponegoro \\ J1. Prof. Soedharto SH, Tembalang, Semarang 50275 \\ dn.psiundip@gmail.com
}

\begin{abstract}
The death of spouse brings major changes in the life of the wife/husband that may affect their psychological well-being. To maintain their psychological well-being within an optimum level, elderly will seek sources of social support in their lives. This study aims to test the correlation between perceived social support and psychological well-being in elderly and to investigate gender differences in perceived social support and psychological well-being. This study comprised 112 elderly (78 widowers; 34 widows), members of the Healthy Elderly Community of the Indonesian Red Cross, Semarang City. Data were collected using the Perceived Social Support Scale (32 items; $\alpha=0.97$ ) and Psychological Well-being Scale (33 items; $\alpha=0.92$ ). Simple regression analysis was applied to test the correlation between two variables and student t-test was used to compare data from male and female groups. The results revealed a positive and significant correlation between perceived social support and psychological well-being in elderly $(r=0.739 ; p<0.001)$. Perceived social support explained $54.6 \%$ of the psychological well-being. T-test revealed gender differences in perceived social support and psychological well-being in elderly. The widows perceived social support better than the widowers $(t(35)=$ 3.594; $p<0.001)$, the widows also showed higher psychological well-being than the widowers $(t(42)=2.944 ; p$ $=0.004)$.
\end{abstract}

Keywords: psychological well-being, social support, gender, elderly, widow, widower

\begin{abstract}
Abstrak
Meninggalnya pasangan hidup membuat seorang istri/suami mengalami banyak perubahan hidup yang mempengaruhi kondisi kesejahteraan psikologisnya. Untuk mempertahankan kesejahteraan psikologis yang baik, lansia akan mencari sumber-sumber dukungan sosial dalam hidupnya. Tujuan dari penelitian ini adalah melihat hubungan antara persepsi terhadap dukungan sosial dan kesejahteraan psikologis lansia janda dan duda dan mengkaji perbedaan gender dalam persepsi terhadap dukungan sosial dan kesejahteraan psikologis diantara janda dan duda. Subjek penelitian ini adalah 112 lansia anggota Paguyuban Lansia Sehat PMI Cabang Kota Semarang (78 janda; 34 duda). Data dikumpulkan menggunakan Skala Persepsi terhadap Dukungan Sosial (32 aitem; $\alpha=$ 0,97 ) dan Skala Kesejahteraan Psikologis (33 aitem; $\alpha=0,92$ ). Teknik analisis regresi sederhana digunakan untuk menguji korelasi; Uji-t digunakan untuk menganalisis perbedaan diantara dua kelompok data yang berbeda berdasarkan gender. Hasil analisis data menunjukkan terdapat hubungan positif yang signifikan antara persepsi terhadap dukungan sosial dan kesejahteraan psikologis pada lansia ( $\mathrm{r}=0,739 ; p<0,001)$. Hasil Uji-t menunjukkan lansia janda/duda memiliki persepsi lebih positif terhadap dukungan sosial $(t(35)=3,594 ; p<$ $0,001)$ dan menunjukkan kesejahteraan psikologis yang lebih baik daripada lansia duda/janda $(t(42)=2,944 ; p=$ $0,004)$.
\end{abstract}

Kata kunci: kesejahteraan psikologis, dukungan sosial, gender, lansia, janda, duda

\section{PENDAHULUAN}

Tidak seorangpun sanggup membayangkan akan ditinggal meninggal oleh orang yang terdekat (pasangan hidup) baik istri maupun suami. Terlebih lagi jika mereka telah hidup bersama sebagai pasangan suami-istri selama belasan bahkan puluhan tahun, 
maka tidak mudah menjalani hari-hari tanpa pasangannya. Secara umum, kehilangan yang paling sulit dilalui adalah kehilangan pasangan hidup (Santrock, 2006).

Hidup menjanda atau menduda berbeda bagi pria dan wanita, terlebih pada lansia. Lansia mengalami penurunan dalam segala aspek, termasuk fisik dan kesehatan. Pada lansia perempuan, dampak menjanda yang harus dihadapi adalah perasaan kesepian. Umumnya anak-anak sudah mandiri dan berumah tangga, rumah terasa sepi dan berbagai masalah ekonomi dan sosial harus mereka selesaikan sendiri. Sebagai solusi, umumnya lansia perempuan tinggal dengan salah satu anaknya yang sudah berumah tangga agar dapat terawat. Sementara lansia pria cenderung lebih tabah ketika ditinggal meninggal pasangannya. Lansia pria biasanya tidak lama menduda; keterbatasan dalam merawat diri men-dorongnya untuk kembali menikah. Tidak jarang kehidupan barunya mendapatkan perlawanan dari anak-anaknya sehingga kondisi psikologis lansia pria yang menikahlagi tidak selalu lebih sehat.

Kebahagiaan serta kesuksesan di masa tua merupakan dambaan setiap individu yang memasuki masa dewasa akhir. Kebahagiaan dan kesuksesan lansia dapat tercapai dengan terpenuhinya kebutuhan akan kesejahteraan psikologis (psychological well-being). Menurut Ryff (dalam Ryff \& Keyes, 1995), secara psikologis manusia yang memiliki sikap positif terhadap diri dan orang lain adalah manusia yang mengakui dan menerima berbagai aspek yang ada dalam dirinya, baik yang bersifat baik maupun buruk serta merasa positif dengan kehidupan masa lalunya, memiliki relasi positif dengan orang lain, mampu melakukan dan mengarahkan perilaku secara mandiri, penuh keyakinan diri (otonomi), dapat melakukan sesuatu bagi orang lain (memiliki tujuan hidup), dapat mengembangkan potensi diri sesuai dengan kapasitas yang dimiliki, mampu mengambil peran aktif dalam memenuhi kebutuhannya melalui lingkungan. Muncul pertanyaan, bagaimanakah kesejahteraan psikologis lansia yang hidup menjanda/menduda?

Sebagai mahkluk sosial, dalam mencapai kebahagiaannya, lansia membutuhkan orang lain untuk berinteraksi. Berkaitan dengan kesejahteraan psikologis, persepsi terhadap dukungan sosial juga mempengaruhi keadaan lansia. Kekuatan dukungan sosial yang berasal dari relasi yang terdekat, seperti keluarga, merupakan salah satu proses psikologis yang dapat menjaga perilaku sehat seseorang (Carstensen, 2003). Lansia yang tinggal sendiri karena perceraian atau kematian pasangan, tentunya tidak lagi menerima dukungan sosial dari pasangannya. Sebagai lansia janda/duda, mereka akan mencari sumber dukungan sosial lainnya, seperti anak/cucu, teman, atau komunitas yang diikuti (Kompas, 30 Mei 2013).

Dukungan sosial didefinisikan oleh House (dalam Kuntjoro, 2002) sebagai transaksi interpersonal yang melibatkan satu atau lebih aspek-aspek berikut: informasi, perhatian, emosi, penilaian, dan bantuan instrumental. Tersedianya dukungan sosial akan membuat individu merasa dicintai, diperhatikan, dihargai, dan menjadi bagian dalam kelompok. Dukungan sosial yang diterima individu pada saat yang tepat, dapat memberikan motivasi dan semangat bagi individu dalam menjalani hidupnya karena dirinya merasa diperhatikan, didukung, dan diakui keberadaanya. Schiffman (dalam Coren, Ward, \& Enns, 2001) mengatakan bahwa persepsi individu tidak didasarkan pada proses kognisi saja, akan tetapi juga melibatkan unsur perasaan. Persepsi terhadap dukungan sosial adalah penilaian secara kognitif dan afektif berdasarkan pengalaman bersama keluarga dan teman mengenai dukungan emosional, informasi, instrumental dan penghargaan. 
Penelitian yang dilakukan oleh Kim \& Moen (2007) terhadap lansia di sejumlah negara di Asia Tenggara, menemukan bahwa dukungan emosional terbesar yang mereka dapatkan berasal dari teman-teman dan tetangga $(55,7 \%)$, diikuti oleh dukungan dari anggota keluarga $(36,5 \%)$. Dalam hal dukungan instrumental, mayoritas $(58,0 \%)$ lansia tidak menerima, $39,2 \%$ lansia menerima instrumental dari keluarganya, dan 2,7\% lansia mendapatkan dukungan instrumental yang berasal dari teman-temannya. Penelitian tersebut juga menegaskan keluarga sebagai sumber utama dukungan sosial bagi anggotanya.

Berdasarkan paparan sebelumnya dapat disimpulkan bahwa salah satu faktor yang dapat mempengaruhi kesejahteraan psikologis lansia adalah persepsi lansia terhadap dukungan sosial yang diterima dari lingkungan (Kiefer \& Sailing, 2002). Persepsi terhadap dukungan sosial adalah penilaian secara kognisi dan afeksi berdasarkan pengalaman bersama keluarga dan teman mengenai dukungan emosional, informasi, instrumental dan penghargaan.

Hipotesis yang diajukan dalam penelitian ini adalah:

1. Ada hubungan positif yang signifikan antara persepsi terhadap dukungan sosial dengan kesejahteraan psikologis lansia janda dan duda. Semakin positif persepsi terhadap dukungan sosial, maka semakin tinggi kesejahteraan psikologis lansia.

2. Terdapat perbedaan persepsi terhadap dukungan sosial pada lansia janda dan duda.

3. Terdapat perbedaan kesejahteraan psikologis pada lansia janda dan duda.

\section{METODE}

Populasi penelitian ini adalah lansia yang tergabung dalam Paguyuban Lansia Sehat PMI Cabang Kota Semarang dengan jumlah 78 lansia janda dan 34 lansia duda. Penelitian ini menggunakan studi populasi, yaitu menggunakan seluruh populasi sebagai subjek penelitian. Data dikumpulkan dengan menggunakan Skala Persepsi terhadap Dukungan Sosial (32 aitem; $\alpha=0,97)$ dan Skala Kesejahteraan Psikologis (33 aitem; $\alpha=0,92$ ).

Penelitian ini dilakukan dengan rancangan studi korelasional dengan teknik analisis data analisis regresi sederhana; sekaligus melihat kontribusi persepsi terhadap dukungan sosial terhadap kesejahteraan psikologis. Perbedaan persepsi terhadap dukungan sosial dan kesejahteraan psikologis pada lansia janda dan duda dihitung dengan menggunakan uji-t.

\section{HASIL DAN PEMBAHASAN}

Hasil perhitungan menggunakan SPSS versi 21.0 menunjukkan adanya korelasi positif yang signifikan antara persepsi terhadap dukungan sosial dengan kesejahateraan psikologis lansia di Paguyuban Lansia Sehat PMI Kota Semarang $(r=0,739 ; p<$ $0,001)$. Dalam penelitian ini, persepsi terhadap dukungan sosial memberikan kontribusi terhadap kesejahateraan psikologis lansia sebesar 54,6\%.

Bila dikaji secara mendetil, diketahui bahwa mayoritas lansia di Paguyuban Lansia Sehat Kota Semarang (50 dari 112; 44,6\%) memiliki kesejahteraan psikologis dalam kategori tinggi, 42 orang $(37,5 \%)$ tergolong kategori sedang, dan $20(17,9 \%)$ lansia memiliki kesejahteraan psikologis rendah. Pada umumnya mereka yang memiliki kesejahteraan psikologis tinggi mengambil peran aktif dalam memenuhi 
kebutuhannya, bersikap mandiri, mampu bertahan dari tekanan sosial, serta mampu menunjukkan sikap positif terhadap dirinya.

Untuk mencapai kesejahteraan psikologis yang tinggi, lansia membutuhkan dukungan sosial, baik dari anak/cucu atau temanteman paguyuban. Hal ini diperjelas Winnubust (dalam Sugiharto, 2010) yang mengatakan bahwa dukungan sosial tidak terlepas dari hubungan yang akrab dengan orang lain, sehingga dari interaksi tersebut individu menjadi lebih mengetahui bahwa orang lain telah memperhatikan, mencintai, dan menghargai dirinya.

Dukungan sosial merupakan faktor dominan yang mempengaruhi kesejahteraan psikologis lansia. Dengan adanya dukungan sosial, lansia merasa diperhatikan, bernilai, dan dicintai, sehingga mendukung kesejahteraan lansia tersebut.
Dukungan sosial merupakan hubungan interpersonal yang di dalamnya berisi pemberian bantuan yang melibatkan aspekaspek informasi, perhatian emosi, penilaian dan bantuan instrumental yang diperoleh lansia melalui interaksi dengan keluarga dan teman sebayanya, yang membantu mereka mengatasi masalahnya. Peneliti juga melakukan analisis terhadap ada/tidaknya perbedaan persepsi terhadap dukungan sosial dan kesejahteraan psikologis antara lansia janda dan duda. Hasil uji-t dipaparkan dalam Tabel 1.

Tabel 1 menunjukkan adanya perbedaan yang signifikan antara lansia janda dan lansia duda dalam hal persepsi terhadap dukungan sosial dan kesejahteraan psikologis. Lansia janda memiliki persepsi yang lebih positif terhadap dukungan sosial dibandingkan lansia duda $\left(M_{\mathrm{Janda}}=132,77\right.$ $\pm 10,24 ; \quad M_{\text {Duda }}=78,97 \pm 9,74 ; \quad t(35)=$ 3,594; $p<0,001)$. Disamping itu, lansia

Tabel 1.

Hasil Uji-t Persepsi terhadap dukungan sosial dan kesejahteraan psikologis lansia janda dan duda

\begin{tabular}{|c|c|c|c|c|}
\hline \multirow[t]{2}{*}{ Variabel } & Janda $(n=78)$ & Duda $(n=34)$ & \multirow[t]{2}{*}{$\mathrm{F}$} & \multirow[t]{2}{*}{$p$} \\
\hline & $M \pm S D$ & $M \pm S D$ & & \\
\hline Kesejahteraan Psikologis & $145,09 \pm 12,11$ & $85,07 \pm 10,87$ & 2,944 & $0,004 * *$ \\
\hline Persepsi terhadap Dukungan Sosial & $132,77 \pm 10,24$ & $78,97 \pm 9,74$ & 3,594 & $<0,001 * *$ \\
\hline
\end{tabular}

Kontribusi persepsi dukungan sosial terhadap kesejahteraan psikologis menunjukkan bahwa lansia di Paguyuban Lansia Sehat Kota Semarang merasakan ketersediaan sumber dukungan sosial yang dapat diandalkan, baik dari keluarga maupun teman se-paguyuban, sehingga mereka memiliki kesejahteraan psikologis yang baik, seperti timbulnya perasaan memiliki, meningkatkan harga diri, dan kejelasan identitas diri serta memiliki perasaan positif mengenai diri sendiri. janda juga memiliki kesejahteraan psikologis yang lebih tinggi daripada lansia duda $\left(M_{\text {Janda }}=145,09 \pm 12,11 ; \quad M_{\text {Duda }}=\right.$ $85,07 \pm 10,87 ; t(42)=2,944 ; p=0,004)$.

\section{KESIMPULAN}

Berdasarkan hasil analisis data, dapat disimpulkan bahwa:

1. Terdapat hubungan positif dan signifikan antara persepsi terhadap dukungan sosial dan kesejahteraan psikologis pada lansia $(r=0,739 ; p<0,001)$. 
2. Terdapat perbedaan persepsi terhadap dukungan sosial dan kesejahteraan psikologis antara lansia janda dan duda. Lansia janda memiliki persepsi yang lebih positif terhadap dukungan sosial dibandingkan lansia duda $\left(M_{\text {Janda }}=\right.$ $132,77 \pm 10,24 ; M_{\text {Duda }}=78,97 \pm 9,74$; $t(35)=3,594 ; p<0,001)$. Disamping itu, lansia janda juga memiliki kesejahteraan psikologis yang lebih tinggi daripada lansia duda $\left(M_{\mathrm{Janda}}=145,09 \pm 12,11\right.$; $M_{\text {Duda }}=85,07 \pm 10,87 ; t(42)=2,944 ; p$ $=0,004)$.

\section{DAFTAR PUSTAKA}

Carstensen, L. L. (2003). Growing old or longevity. California: Stanford University.

Coren, S., Ward, L. M., \& Enns, J. T. (2001). Sensation and perception. Fort Worth: Harcourt College Publishers

(2013). Lansia-lansia yang hidup sendirian. Harian Kompas, 30 Mei, h.6.
Kiefer, S. M. \& Sailing, P. (2002). Retirement and leisure time. Journal of Psyciatric; $10-28$.

Kim, J. \& Moen, P. (2007). Retirement transitions, social support, and psychological well-being: A life-course approach. Journal of Gerontology: Psychological Sciences 57B:P212$\mathrm{P} 222$

Kuntjoro, Z. S. 2002. Dukungan sosial pada lansia. (Online). (http://www.epsikologi.com $\underline{160802 . h t m, ~ d i a k s e s ~ N o v e m b e r ~ 2009) . ~}$

Ryff, C. D. \& Keyes, C. L. M. (1995). The structure of psychological well-being revisited. Journal of Personality and Social Psychology, 69, 719-727.

Santrock, J. W. (2006). Life span development. New York: McGraw Hill.

Sugiharto, C. (2010). Hubungan antara dukungan sosial dengan kepuasan hidup pada lansia di Panti Wreda " $x$ " Bandung. Tesis. Universitas Padjadjaran, Bandung. 